\title{
Determination of the evaluation criteria for agritourism via delphi and analytic hierarchy process methods: a case study in Turkey
}

\section{Tarım Turizmi Değerlendirme Kriterlerinin DELPHI ve Analitik Hiyerarşi Süreci Yöntemleriyle Belirlenmesi: Türkiye'de Bir Vaka Çalışması}

\author{
Ahmet Serhat ULUDAĞ ${ }^{1}$ \\ Evrim ERDOĞAN YAZAR ${ }^{2}$
}

\author{
https://orcid.org/0000-0002-0058-2384 \\ https://orcid.org/0000-0001-8689-4137
}

\begin{abstract}
ÖZET
Her heçen gün tarım arazilerinin olduğu bölgelerde nüfus azalmakta, tarımsal araziler etkin ve verimli kullanılamamakta; söz konusu bölgeler ve bu bölgelerde yaşayanlar ekonomik, sosyal ve kültürel açılardan biraz daha fazla geriye gitmektedirler. Bu çalışma, kırsal kalkınma için alternatif opsiyonlardan biri olan tarım turizminini farklı bir açıdan incelemektedir. Bu bağlamda çalışmanın temel amacl, tarım turizmi değerlendirme kriterlerini belirlemek ve ağırlıklandırmaktır. Bu amaçla Delphive Analitik Hiyerarşi Süreci yöntemleri gibi karar verme teknikleri kullanılmıştır. Üç turdan oluşan bir Delphi çalışmasıyla üzerinde uzlaşmaya varılan 52 adet tarım turizmi değerlendirme kriteri belirlenmiştir. Belirlenen kriterlerin öneciliklerinin tespiti ve ağırlıklarının hesaplanması için Analitik Hiyerarşi Süreci yöntemi kullanılmıştır. Bu yolla, herhangi bir bölgenin tarım turizmi potansiyelinin var olup olmadığının tespit edilmesine yönelik yapılacak çalışmalara katkı sağlanması amaçlanmıştır.
\end{abstract}

Anahtar Kelimeler: Tarım Turizmi, Delphi Tekniği, Analitik Hiyerarşi Süreci

JEL Kodları: M10, M11, M30, Z30

\begin{abstract}
The population is decreasing in the regions where agricultural lands are prevalent, agricultural areas are not used effectively and efficiently, and both the afore-said regions and the people living there show a recession with each passing day in terms of economic, social and cultural aspects. This study examines from a different perspective the agritourism, which can be considered as an alternative option for rural development. Accordingly, the main objective of the study is to determine and weight the evaluation criteria for agritourism. Decision-making techniques such as Delphi and Analytic Hierarchy Process methods have been used for this purpose. 52 evaluation criteria have been determined by common consent through a Delphi study consisting of three rounds. The Analytic Hierarchy Process (AHP) method has been used for the calculation of specified criteria weights. In this way, it has been aimed to contribute to the studies that will be carried out in order to determine the existence of agritourism potentials in any region.
\end{abstract}

Keywords: Agritourism, Delphi Technique, Analytic Hierarchy Process

JEL Codes: M10, M11, M30, Z30

\section{INTRODUCTION}

Rural areas face with numerous disadvantages such as the low income levels of most of the people living in rural regions, the low amount of savings that can be invested in the region, the traditionality of the economic activities generally based on agriculture and livestock, and social impossibilities arising from economic underdevelopment. On the other hand, there are new opportunities in the rural areas for policy makers as well as the people living in the region and wishing to have higher incomes and living standards, thanks to high potentials of the above-mentioned areas in terms of natural beauty, rural lands, wildlife, landscapes, and historical and cultural values. 
At this point, tourism and alternative tourism types draw attention as a sector or an option offering new opportunities for the development of rural areas (Möller et al, 2014). Tourism and alternative tourism types do not negatively influence the basic economic activities and living standards of the people residing in the rural areas; on the contrary, they make great contribution to the individuals as well as the region itself by providing new benefits and additional income. This is because the fulfilment of tourism-based activities, which do not necessitate high amount of capitals, will create economic benefits through the sale of handicrafts and products based on regional production while the people living in rural areas continue to perform their basic economic activities (Sarıkamış and Bahar, 2013). When tourism-based activities are evaluated from this perspective, they can be seen as a force motivating the development of rural areas because the activities to be carried out in the rural lands will reinforce the attractiveness of the region.

Agritourism, one of the rural tourism types, is a tourism-based activity offering the opportunity to travel, to learn, to explore and to be a part of the nature and countryside as well as enabling the tourists to know about the agricultural lands, daily tasks of the people living in the region, regional products, traditional cuisine and cultural items (Gordean et al., 2009).

Agritourism offers great opportunities within the scope of rural development for the countries such as Turkey or characteristically similar territories in which agricultural sector constitutes a large proportion of the economy and enjoys higher employment rates, and where the agricultural lands cover much of the total surface area of the country. The possibility of transforming the high potential of agritourism in the countries such as Turkey into great opportunities is closely related to the effectiveness of the decisions for the investments in agritourism. An investment decision aiming at the development through agritourism should take into account the investment zone, the criteria that will be demanded for the determination of the afore-said area, the selection of the products and/ or values to be prioritized in the region, the amount of the resources, and the expectations from the labor, time and investment to be allocated. For this reason, such investment decisions are complex processes in which many factors interact with each other and which must be dominated by analytical thinking.

In order to put into practice a project that is suitable for agritourism, it is important to know which region is appropriate for agritourist and which criteria will be used in the evaluation process of these regions. After identifying the criteria, other subject to be determined is evaluating the weights and significance of the criteria. Lastly; it is also important to determine which value of agriculture will be prioritized in the selected region or what the tourism-based activities will focus on. From this point of view, this study firstly aims to determine the evaluation criteria for agritourism, and then to calculate their weights. In this way, it is intended to contribute to the studies that will be carried out in order to choose the most appropriate agricultural area among many regions having high potential in terms of agritourism.

\section{CONSIDERATIONS FOR CONCEPTUAL ISSUES RELATED TO AGRITOURISM}

Agritourism is a type of rural tourism which allows the tourists to travel, to learn, to explore and to be a part of the nature, and to know about the agricultural areas in rural regions, the agricultural activities of the people living there, the regional products, the traditional cuisine, the cultural items and many other activities and values that are unique to the region (Gordean et al., 2009). Although there is no consensus about the definition of agritourism, certain common features have been observed among the numerous definitions in the literature. In this context, almost all definitions emphasize the concepts of "farm" and "tourism-based activity carried out in addition to the main scope of tourism". Besides, some definitions underline the flexible capacity of agritourism which can be performed with or without accommodation (Busby and Rendle, 2000; Phillip et al., 2010). Moreover, various studies indicate that the performance of touristic activities in villages or on farms provides a distinctive feature in terms of conceptual aspects. In this approach, the concept of "farm tourism" is used when the touristic activities in rural areas are carried out on the farms. Similarly, the concept of agritourism is preferred for the cases where the tourism-based activities are performed in the villages in which economic practices are predominantly based on agriculture (Ahipaşaoğlu and Çeltek, 2006). López and García (2006) have stated that the tourists should stay in the house of a farmer and/or a peasant so that this touristic activity can be defined as agritourism. Besides, it is emphasized that all family members should take part in the fulfilment of the tourism activity and that they should accommodate the tourist with the opportunity to be in harmony with nature in a remote and peaceful environment in 
order that this process can be considered as a part of agritourism.

When the common points of the definitions in the literature are taken into consideration, agritourism can be defined as a type of rural tourism creating economic benefits by means of agricultural activities, agricultural production and sale of the agricultural products, allowing these agricultural activities to be performed in the farms, villages, agricultural lands and/or residences belonging to the people of the region, and enabling the farmers that are wishing to have additional income to open their gates to the tourists for a fee so that the guests can get rid of the pressure of their daily lives in their crowded and noisy environment, they can have different experiences, they can eat the agricultural products in their natural environment, they can participate in the agricultural activities directly, and they can observe the local culture and lifestyle individually.

Within the scope of agritourism, the families living in the rural areas can conduct the tourism management process on a smaller scale by arranging their farms and/or lands as residences and recreational areas where leisure time activities can be performed (Kozak and Bahçe, 2009). The agritourism provides certain basic advantages although these positive outcomes may differ in various countries and even in different regions of the same country. The mentioned advantages of agritourism include the provision of non-agricultural income for the people living in the rural areas, the improvement of the living conditions of these people, the contribution to the social and economic development of the region (lakovidou et al., 2001). Yavuzaslanoğlu and Yavuz (2012) have also emphasized some additional advantages of agitourism such as the protection of the existing population in rural areas, the promotion, protection and support of local agricultural activities, local handicrafts, local architecture and cultural heritage, the conservation of the environment and biodiversity, the contribution to the sustainability, the support of rural entrepreneurship, the provision of new employment opportunities, the promotion of the workforce, the improvement of the infrastructure facilities in rural areas, the reinforcement of the communication and cultural exchange between the rural regions and city centers, the awareness-raising for the local people, and the maintenance of the sustainability through the optimum utilization of resources (Yavuzaslanoğlu and Yavuz, 2012).

The agritourism is in the field of interest of the individuals from a small group due to its specific features.
In other words, the agritourism aims at the individuals and their niche markets having more specific demands and interests. The members of the above-mentioned niche markets usually consist of the individuals having a high level of education and career, belonging to a young or middle age class, having middle or high income, being responsible for a family, preferring to travel with private vehicles instead of public transportation or tourism agencies, seeing the rural areas as the places where social activities can be performed (lakovidou et al., 2001), living in the cities, wishing to get rid of daily pressures by spending time in the nature, desiring to know the rural life and culture, and seeking authentic experiences (Aikaterini et al., 2001).

\section{A CASE STUDY: DETERMINATION AND CALCULATION OF THE CRITERIA FOR AGRITOURISM}

The literature review performed on the studies related to the agritourism has demonstrated that there is no criterion that can be used for deciding whether a region is suitable for agritourism or not. The studies regarding this issue, including the ones conducted in Turkey, have been carried out mainly on the activities of sustainable and/or rural tourism. The main methods used for determining these criteria are SWOT analysis, questionnaires for experts, local people and tourists (Ko, 2001; Sharpley, 2002; Kılıç and Kurnaz, 2010; Kızılaslan and Ünal, 2013; Dymond, 1997), expert opinions or various decision-making techniques as Delphi, Analytic Hierarchy Process, Ecological Footprint and Principal Component Analysis (Briedenhann and Butts, 2006; Tsaur and Wang, 2007; Hunter and Shaw, 2007; Choi and Sırıkaya, 2006; Blancas et al., 2011; Park and Yoon, 2011; Siow et al., 2011).

This study, which has been prepared for achieving has four main objectives which are listed as follows: (1) Determination of the evaluation criteria for agritourism. (2) Calculation of evaluation criteria weights. (3) Contribution to the relevant literature by using the qualitative and quantitative decision-making methods and techniques in a different field such as agritourism. (4) Provision of input for decision-making problems necessitating a selection among the alternative regions potentially suitable for agritourism practices.

In line with the main objectives mentioned above, it has been decided to use the Delphi and AHP methods in an integrated manner. First of all, a literature review has been performed to determine the evaluation criteria for agritourism. Then the criteria suitable 
for agritourism have been transferred to the Delphi technique. The Delphi process, starting with the above-mentioned criteria and the new ones added at the end of the first round of Delphi technique, has been finalized with the determination of the final criteria. The Analytical Hierarchy Process (AHP), has been used to calculate weights of the evaluation criteria for agritourism, determined with the Delphi Technique.

\subsection{Methods}

This section provides detailed explanations regarding the AHP methods and the Delphi technique used for analysis.

\subsubsection{Delphi technique}

The DELPHI Project is the name of a study carried out in the RAND Company on an intermittent basis and based on the use of expert opinions, and the technique used in this project is called as Delphi method. The objective of the method is defined as the attainment of the most reliable common opinion that a group of experts have agreed upon. It is stated that the experts should receive a series of intensive questions giving feedbacks for their controlled ideas in order to attain the afore-said common opinion (Dalkey and Helmer, 1963). This technique developed in 1963 by Dalkey and Helmer is a widely accepted method that is used to achieve the convergence of real-world views expressed by the experts of a particular subject (Hsu and Standford, 2007).

The main force that stimulates the development of the technique is the perception indicating that the outcomes obtained from a pool in which individual opinions are evaluated together will yield more accurate results than the views analyzed individually. In this sense, the technique ensures that the experts develop a consensus systematically while making predictions about the future (Fusfeld and Foster, 1971). It is also accepted as a unique method used for obtaining the final decision of a group considering the fact that the group consisting of " $n$ " persons can make more rational predictions when precise information cannot be obtained, and for clarifying their judgements. Basically, the Delphi technique is utilized for the achievement of main objectives such as the identification and arrangement of alternatives, the exploration and disclosure of the information and assumptions pioneering different judgements, the search for any information agreed upon by some of the respondent group, and the association of the judgements about an issue covering a broad discipline (Van De Ven and
Delbecq, 1974), and it is preferred in numerous fields such as program planning, assessment of needs, policy making and resource allocation (Hsu and Standford, 2007). The Delphi process has three distinct characteristics: anonymity, feedback, and group response (Jolson and Rossow, 1971). Anonymity is ensured by means of the questionnaires combining the ideas, and it reduces the impacts of individuals. Controlled feedback is provided through the forms presenting the statistical summaries of the group ideas sent to the participants for being used at the later stage of the study. At the same time, this type of feedback is accepted as a means to reduce the noise in the process. The statistical group response represents the statistical scores calculated in line with the responses taken for each topic, and it is used for ensuring the reliability through the elimination of group pressure (Fischer, 1978). In addition to these features, the Delphi technique has other specific characteristics which can be listed as being a recurrent process (Landeta, 2006), consisting of iterations or serial rounds (Woudenberg, 1991), using a panel of experts for data collection, preventing the face-to-face discussions among the participants, providing the judgements or consensus systematically, and using the frequency distributions in defining the agreement patterns among the participants (McKenna, 1994).

The methods of qualitative and quantitative data analysis are used in the Delphi process. The researchers collect the qualitative data in the first round by using the literature reviews and open-ended questions, if available. Other rounds continue to be carried out until the panellists reach the desired level of compromise. The measures of central tendency (mean, median and mode) and central dispersion (standard deviation and range) are used at this stage of the Delphi process (Hsu and Standford, 2007). There are different types of Delphi technique such as Classical Delphi, Modified Delphi, Decision Delphi, Political Delphi, Real-time Delphi, E-Delphi, Technological Delphi, Online Delphi, Argument Delphi and Solver Delphi (Keeney et al., 2011).

The Delphi technique consists of a series of steps comprising the identification of the problem, the selection of the experts, the submission of the open-ended questions to the participants, the repeated submission of the structured questionnaire following the responses to the open-ended question, the analysis of the questionnaire at the end of three or more rounds and the finalization of the practice. 
Once the objective of the research and the subject matter of the problem are identified, a group should be organized by ensuring the participation of the experts having relevant information and experience on the issue. The expert/s taking part in the group should be selected among the ones who have enough knowledge about the subject of the research, who are interested in the subject and/or have experience in the field, and who can also carry out a discussion about the issue (Keeney et al., 2011; Thangaratinam and Redman, 2005). The number of the experts may vary according to the purpose and design of the project, and the time required for data collection (Keeney et al., 2011). In this context, it is impossible to say that there is a consensus about the number of experts. However, Linstone and Turoff (2002) remark that seven experts have delivered the best performance in the assessment of the status within the scope of the studies carried out with numerous groups consisting of experts in different numbers while Akins et al. (2005) state that the best number of experts may vary from 10 to 100 .

The number of the rounds is another important issue in the Delphi technique apart from the number of experts. Classical Delphi process consists of four rounds; nevertheless, this number may be reduced to two or three rounds as seen in the studies of Procter and Hunt (1994), Green et al. (1999), and Skulmoski et al. (2007). However, in theory, the Delphi technique continues to be applied until a consensus is reached. On the other hand, various researchers argue that three rounds are enough to obtain necessary information or to reach a consensus on an issue (Hsu and Standford, 2007). In this regard, the generally accepted number of rounds is three at the minimum if there is an open-ended question (Thangaratinam and Redman, 2005). In the light of these discussions, it is possible to say that the Delphi method used for data collection consists of three rounds, and that this number may be increased if necessary.

Traditionally, the first round begins with the demands for the comments and views of the panellists in order to form an opinion about the topic (Keeney et al., 2011). The questions on the subject matter of the research are sent to the panellists who are qualified as experts. The first round generally starts with open-ended questions (Hsu and Standford, 2007). The structured questionnaires are prepared through the combination of the feedbacks obtained from each panellist in the rounds coming after the first round. These questionnaires are then sent back to the panellists after being analyzed (Keeney et al., 2011). The questionnaires prepared in the second round are the results of the ideas or items obtained in the first round. It may be asked whether the panellists agree upon the ideas or the items indicated in the questionnaire. Moreover, the panellists may be asked to grade the importance of these items. Generally, a Likert-type questionnaire is formed in the second round. In the third and fourth rounds, the judgements are graded so that a compromise is reached on the items of questionnaire structured after the first and second rounds. The third round is commonly used by panellists to make a better classification. The fourth round is usually the last one, and it offers an opportunity for the participants to reconsider their ideas. The list of the items, agreed upon after the other rounds, is redistributed to the panellists (Hsu and Standford, 2007).

The level of compromise should be determined in all rounds except the first round. There is no consensus on the exact level of compromise because this level may vary according to the number of samples, the aim of the research, and the resources (Hasson et al., 2000). Williams and Webb (1994) suggest that the compromise should be at the highest level, which means $100 \%$, while this level is expected to be $90 \%$ by Hung et al. (2008). On the other hand, Loughlin and Moore (1979) claim that $51 \%$ is enough for the level of compromise.

\subsubsection{Analytic hierarchy process method}

AHP proposed by Thomas L.Saaty for the purpose of determining the relative importance of successive activities (Dağdeviren et al., 2009) is quite suitable for multiple-criteria decision-making problems necessitating to make a selection among many options in order to evaluate numerous measurable and unmeasurable factors together (Saaty, 1986). The basic processes required to achieve the solution in AHP, which has a fairly simple and understandable mathematical form, are shown step by step as follows with reference to Çelikbilek (2018), Yıldırım ve Önder (2014), Özbek (2018), Aktaş et al. (2015) works.

Stage 1: The main and sub-criteria of decision, the options and the objective to be achieved should be clearly defined in the first stage of the AHP.

Stage 2: In the second stage, a hierarchical structure should be established in order to reflect the relationship between the layers formed by successive elements. 
Stage 3: In the third stage, pairwise comparison matrices should be constructed by means of the relative importance scale (Table 1 ).

Table 1: Relative Importance Scale

\begin{tabular}{ll}
\hline $\begin{array}{l}\text { Degree of } \\
\text { Importance }\end{array}$ & Definition \\
\hline 1 & Equal Importance \\
\hline 3 & Moderate Importance \\
\hline 5 & Strong Importance \\
\hline 9 & Very Strong or Demonstrated Importance \\
\hline $2,4,6,8$ & Extreme Importance \\
\hline
\end{tabular}

(Saaty, 2008)

Stage 4: The fourth stage should focus on the calculation of the local weights reflecting the individual weights of the main and/or sub criteria and the global weights representing their weights within the scope of all criteria. The equation shown in Equation (1) is used for calculating the weights. In equation (1), $\lambda_{\text {max }}$ which should be calculated through the use of Equation (2) is the largest eigen value of matrix (A)

$$
\begin{aligned}
& A(.) w=\lambda_{\max }(.) w, \quad\left(w=w_{1}, w_{2}, \ldots w_{n}\right) \\
& \lambda_{\max }=\frac{\sum_{j=1}^{n} a_{i j} w_{j}}{w_{j}}, \quad(i=1,2, \ldots, n)
\end{aligned}
$$

In Equality (1):

$$
\begin{array}{ll}
A & : \text { Pairwise Matrix } \\
w & : \text { Eigenvector } \\
n & : \text { Number of criteria }
\end{array}
$$

Stage 5: Consistency ratios (CR) of pairwise comparison matrices should be calculated in the final stage. In this step, the Consistency Index (CI) should be calculated in the first place through the use of Equation ( 3 ) and then the Consistency Ratio ( $C R$ ) should be calculated through the use of Equation (4). The Random Index (RI) values shown in Table 2 are used for the calculation of the consistency ratio.

Consistency Index $(C I)=\frac{\lambda_{\max }-n}{n-1}$

Table 2: Random Index (RI)

\begin{tabular}{lllllllllll}
\hline$n$ & 1 & 2 & 3 & 4 & 5 & 6 & 7 & 8 & 9 & 10 \\
\hline$R I$ & 0 & 0 & 0,58 & 0,90 & 1,12 & 1,24 & 1,32 & 1,41 & 1,45 & 1,49 \\
\hline (Saaty, 1987)
\end{tabular}

Consistency Ratio $(C R)=\frac{\text { Consistency Index }(C I)}{\text { Random Index }(R I)}$

If the consistency ratio calculated for the comparison matrices is less than or equal to 0,1 ; the eigenvector " $w$ " can be used as the weighted vector after the normalization. Otherwise, the comparison matrix needs to be revised (Deng et al., 2014).

\subsection{Data Collection and Analysis}

It has been decided to conduct a Delphi study consisting of 3 rounds in order to determine the evaluation criteria for agritourism. A literature review has been made before the first round of the Delphi study. In this context, 124 criteria have been found in the first place in various studies (Miller 2001; Tsaur and Wang, 2007; Choi and Sirakaya, 2006; Blancas et al., 2011; Park and Yoon, 2011; Twining-Ward and Butler, 2002; Dymond, 1997; Mearns, 2012; Ko, 2001; Reed et al, 2006). Then the number of the criteria has been reduced to 66 through the elimination of repeating and/or similar criteria.

Then, it has been decided to compose a Delphi group consisting of the experts on agritourism. Strict attention has been paid to the selection of the experts who have knowledge and experience on the field. Numerous experts and academicians have been contacted, and they have been asked to contribute to the study. A Delphi group of 14 people ( 5 academicians, 4 experts working in the private sector and 4 experts working in the public sector) has been composed with the participation of the academicians and experts responding positively to the above-mentioned demand. Questionnaire forms prepared with Delphi technique have been delivered to the experts via e-mail, and the responses have been sent via the same platform.

In the first round of the Delphi technique, the members who do not know anything about the identity of other participants and their institutions have been asked to evaluate 66 criteria selected from the literature, to add any other criterion that they think to be necessary, and to indicate the criteria that they propose to exclude. All forms delivered to 14 experts via e-mail have been answered and sent back to the researcher. The responses of the experts have been analyzed, and it has been decided to add 13 new criteria to 66 criteria specified in the first round, and 
to use 79 criteria in the second round of the Delphi technique. ${ }^{* *}$

In the second round of the Delphi technique, each of 14 experts has been asked to score 79 decision criteria by using the 7-point Likert scale shown in Table 3. Since 2 of 14 experts did not send their responses in the second round, these two experts have been excluded from the group and the evaluation process. In this context, the response rate of the second round turnover has been measured to be approximately $86 \%$. The results of the second round and the statistical calculations have been sent to 12 experts via e-mail in the third and final round of the Delphi technique. All questionnaires have been responded, and the Delphi study has been completed at the end of the third round.

52 evaluation criteria have been determined for agritourism with the use of the Delphi technique, and the second stage of the study has started. The Analytic Hierarchy Process method has been used in the second stage of the study. The hierarchical structure that effectively reflects the relationship among the specified criteria has been firstly determined in this stage. Within the scope of this process, 52 evaluation criteria for agritourism have been classified into 9 main categories. 12 experts taking part in the Delphi process have been asked to participate in the study in order to calculate weights of identified criteria. The experts have positively responded to this demand; therefore, they have received via e-mails the forms prepared in accordance with the scale developed by Thomas L.Saaty and shown in Table 1. All forms have been completed and sent back. The study has been finalized after the calculation of the local and global weights of the evaluation criteria for agritourism in the light of expert opinions.

\subsubsection{Determination of the evaluation criteria for agritourism via Delphi technique}

The forms comprising 66 evaluation criteria compiled from the literature have been sent to the experts in the first round of the Delphi Technique which has been used for the determination of the evaluation criteria for agritourism, as stated before. The number of criteria, which was 66 in the first round, has become 79 with the addition of new suggestions. Questionnaires prepared with the use of the scale shown in Table
3 have been sent to the experts via e-mail in in the second round.

Table 3: The Evaluation Scale Used in II. and III. Rounds of the Delphi Method

\begin{tabular}{lc}
\hline Linguistics expressions & $\begin{array}{c}\text { Scores corresponding to } \\
\text { linguistics expressions }\end{array}$ \\
\hline Very unimportant & 1 \\
\hline Quite unimportant & 2 \\
\hline Unimportant & 3 \\
\hline $\begin{array}{l}\text { Neither unimportant nor } \\
\text { important }\end{array}$ & 4 \\
\hline Important & 5 \\
\hline Quite important & 6 \\
\hline Very important & 7 \\
\hline
\end{tabular}

The questionnaires have been statistically analyzed with the help of Excel program. Median (Med), first quartile (Q1), third quartile (Q3) and range (R) values of the data were calculated in accordance with the experts' evaluations on the criteria. The median of a set of observations is the value in the middle if the number of observation is uneven when the observations are arranged in the order of magnitude; on the other hand, if the number of observation is even, this median is the average of the two values in the middle (Newbold, 1995). Quartiles and percentages indicate any point in comparison with other points in the distribution. The quartiles are not a range, but a point. On the other hand, the range indicates the difference between the first quartile and the third quartile (Akgül and Çevik, 2005). The small value of the range indicates that there is a compromise on the relevant criterion. In this context, it is accepted that a compromise is reached on the criteria if their range value is less than 1,2 (Zeliff and Heldenbrand, 1993).

At the end of the second round of Delphi technique, the first quartile (Q1), the third quartile (Q3), median and range $(R)$ values of 79 criteria have been calculated according to the responses of the experts. Calculated range $(R)$ values have demonstrated that a compromise was reached on 42 criteria in the second round of the Delphi technique.

In the third round, the experts have received the evaluations, the calculated values and the statistical explanations of these values recorded in the second round, and they have been asked to revise their evaluations. Statistical calculations have been remade by

${ }^{1 *}$ Since the tables occupy a lot of space, only the results of the third round in Delphi technique are shown in Table 4 while other rounds are only explained in the text. 
taking into consideration the responses of the experts who revised the results and made new evaluations. In this way, the criteria agreed upon by the experts have been determined. The calculated range $(R)$ values have demonstrated that Delphi technique was agreed on 52 decision criteria in the third round. The calculated median, the first quartile, the third quartile and the wi$\mathrm{dth}$ values of the criteria decided in the third round are shown in Table 4. In this table, " $C$ " signifies the criterion while " $j$ " signifies the item number of the criteria ( $j=$ $1,2, \ldots, 79)$.

Table 4. Results of the III. Round in Delphi Technique

\begin{tabular}{|c|c|c|c|c|c|c|c|c|c|c|}
\hline $\begin{array}{l}\text { Cri. } \\
\text { (C) }\end{array}$ & Q1 & Median & Q3 & $R$ & $\begin{array}{c}\text { Accept (ACC) } \\
/ \\
\text { Rejection (REJ) }\end{array}$ & $\begin{array}{l}\text { Cri. } \\
\text { (C) }\end{array}$ & Q1 & Median & Q3 & $\begin{array}{c}\text { Accept (ACC) } \\
/ \\
\text { Rejection (REJ) }\end{array}$ \\
\hline$C_{1}$ & 3,3 & 5 & 5,8 & 2,5 & REJ. & $C_{41}$ & 5 & 5 & 6 & ACC. \\
\hline$C_{2}$ & 1,5 & 3,5 & 4,8 & 3,3 & REJ. & $C_{42}$ & 5 & 6 & 7 & REJ. \\
\hline$C_{3}$ & 5 & 5 & 6 & 1 & ACC. & $C_{43}$ & 5,3 & 6 & 6,8 & REJ. \\
\hline$C_{4}$ & 5 & 5,5 & 6 & 1 & ACC. & $C_{44}$ & 6 & 6 & 6,8 & ACC. \\
\hline$C_{5}$ & 7 & 7 & 7 & 0 & ACC. & $C_{45}$ & 5 & 5,5 & 6 & ACC. \\
\hline$C_{6}$ & 5 & 6 & 6,8 & 1,8 & REJ. & $C_{46}$ & 5,3 & 6 & 7 & REJ. \\
\hline$C_{7}$ & 5 & 5,5 & 6 & 1 & ACC. & $C_{47}$ & 6 & 7 & 7 & ACC. \\
\hline$C_{8}$ & 5 & 5,5 & 6,8 & 1,8 & REJ. & $C_{48}$ & 6 & 7 & 7 & ACC. \\
\hline$C_{9}$ & 6 & 7 & 7 & 1 & ACC. & $C_{49}$ & 6 & 7 & 7 & ACC. \\
\hline$C_{10}$ & 5 & 5 & 6 & 1 & ACC. & $C_{50}$ & 5 & 6,5 & 7 & REJ. \\
\hline$C_{11}$ & 4,3 & 5 & 5,8 & 1,5 & REJ. & $C_{51}$ & 5,3 & 6,5 & 7 & REJ. \\
\hline$C_{12}$ & 5 & 5 & 6 & 1 & ACC. & $C_{52}$ & 5,3 & 6 & 6 & ACC. \\
\hline$C_{13}$ & 4 & 5 & 5 & 1 & ACC. & $C_{53}$ & 5,3 & 6 & 6,8 & REJ. \\
\hline$C_{14}$ & 4 & 5 & 5 & 1 & ACC. & $C_{54}$ & 5 & 5,5 & 6 & ACC. \\
\hline$C_{15}^{14}$ & 4 & 4,5 & 5 & 1 & ACC. & $C_{55}$ & 4,3 & 5 & 6 & REJ. \\
\hline$C_{16}$ & 5 & 5 & 5 & 0 & ACC. & $C_{56}^{35}$ & 6 & 6,5 & 7 & ACC. \\
\hline$C_{17}$ & 4 & 5 & 5 & 1 & ACC. & $C_{57}$ & 6 & 7 & 7 & ACC. \\
\hline$C_{18}$ & 4 & 5 & 5 & 1 & ACC. & $C_{58}^{57}$ & 5 & 5 & 5,8 & ACC. \\
\hline$C_{19}$ & 5 & 5,5 & 7 & 2 & REJ. & $C_{59}^{38}$ & 5 & 5 & 6 & ACC. \\
\hline$C_{20}$ & 4 & 5 & 5 & 1 & ACC. & $C_{60}$ & 6,3 & 7 & 7 & ACC. \\
\hline$C_{21}$ & 5 & 6 & 7 & 2 & REJ. & $C_{61}$ & 5 & 5 & 5,8 & ACC. \\
\hline$C_{22}$ & 4,3 & 5,5 & 7 & 2,8 & REJ. & $C_{62}$ & 5 & 5 & 6 & ACC. \\
\hline$C_{23}$ & 3 & 4 & 5 & 2 & REJ. & $C_{63}$ & 5 & 5 & 6,5 & REJ. \\
\hline$C_{24}$ & 5 & 5,5 & 6 & 1 & ACC. & $C_{64}$ & 5,3 & 7 & 7 & REJ. \\
\hline$C_{25}$ & 5 & 5 & 5 & 0 & ACC. & $C_{65}$ & 5,3 & 6 & 6,8 & REJ. \\
\hline$C_{26}$ & 5 & 5 & 5 & 0 & ACC. & $C_{66}$ & 5,3 & 6 & 7 & REJ. \\
\hline$C_{27}$ & 4 & 5 & 5 & 1 & ACC. & $C_{67}$ & 5 & 5 & 5,8 & ACC. \\
\hline$C_{28}$ & 5 & 5 & 5 & 0 & ACC. & $C_{68}$ & 5 & 5 & 6 & ACC. \\
\hline$C_{29}$ & 5 & 5 & 6 & 1 & ACC. & $C_{69}$ & 5 & 5,5 & 7 & REJ. \\
\hline$C_{30}$ & 5 & 5 & 6 & 1 & ACC. & $C_{70}$ & 4 & 5 & 5,8 & REJ. \\
\hline$C_{31}$ & 5 & 6,5 & 7 & 2 & REJ. & $C_{71}$ & 7 & 7 & 7 & ACC. \\
\hline$C_{32}$ & 5 & 5 & 5,8 & 0,8 & ACC. & $C_{72}$ & 5 & 6 & 6,8 & REJ. \\
\hline$C_{33}$ & 5 & 5 & 5,8 & 0,8 & ACC. & $C_{73}$ & 5 & 5 & 6 & ACC. \\
\hline$C_{34}$ & 6 & 6 & 7 & 1 & ACC. & $C_{74}$ & 5 & 5 & 6 & ACC. \\
\hline$C_{35}$ & 5 & 5 & 6 & 1 & ACC. & $C_{75}$ & 5 & 6 & 6,8 & REJ. \\
\hline$C_{36}$ & 5 & 5 & 5 & 0 & ACC. & $C_{76}$ & 5,3 & 6,5 & 7 & REJ. \\
\hline$C_{37}$ & 5 & 5 & 5 & 0 & ACC. & $C_{77}$ & 4 & 5 & 5 & ACC. \\
\hline$C_{38}$ & 4 & 5 & 5 & 1 & ACC. & $C_{78}$ & 5 & 5 & 6 & ACC. \\
\hline$C_{39}$ & 6 & 7 & 7 & 1 & ACC. & $C_{79}$ & 4 & 5 & 5 & ACC. \\
\hline$C_{40}$ & 4,3 & 5 & 6 & 1,8 & REJ. & & & & & \\
\hline
\end{tabular}

In addition to Table 4, agreed upon 52 criteria using Delphi Technique and their definitions are also shown in Table 5. 
Table 5: An Agreed Upon 52 Criteria Using Delphi Technique

\begin{tabular}{|c|c|c|}
\hline$C_{j}$ & Definitions of Criteria & ACCEPT \\
\hline$C_{3}$ & Educational background & Accept \\
\hline$C_{4}$ & Level of income & Accept \\
\hline$C_{5}$ & Potential demand for agritourism & Accept \\
\hline$C_{7}$ & Presence and diversity of natural plants & Accept \\
\hline$C_{9}$ & Economic added-value of agritourism & Accept \\
\hline$C_{10}$ & Number of domestic and foreign tourists visiting the region & Accept \\
\hline$C_{12}$ & Soil-based agricultural activities & Accept \\
\hline$C_{13}$ & Ovine/caprine breeding & Accept \\
\hline$C_{14}$ & Bovine breeding & Accept \\
\hline$C_{15}$ & Poultry farming & Accept \\
\hline$C_{16}$ & Fishing & Accept \\
\hline$C_{17}$ & Beekeeping & Accept \\
\hline $\mathrm{C}_{18}$ & Number of farms & Accept \\
\hline$C_{20}$ & Labor force employed in the agricultural activities & Accept \\
\hline$C_{24}$ & Diversity of agricultural activities and products & Accept \\
\hline$C_{25}$ & Temperature & Accept \\
\hline$C_{26}$ & Precipitation & Accept \\
\hline$C_{27}$ & Wind & Accept \\
\hline$C_{28}$ & Snow and frost & Accept \\
\hline$C_{29}$ & Soil productivity & Accept \\
\hline$C_{30}$ & Sufficiency of irrigation water & Accept \\
\hline$C_{32}$ & Lands suitable for agriculture & Accept \\
\hline$C_{33}$ & Lands suitable for animal husbandry & Accept \\
\hline$C_{34}$ & Transportability & Accept \\
\hline$C_{35}$ & Presence of endemic plant species & Accept \\
\hline$C_{36}$ & Presence of streams and rivers & Accept \\
\hline$C_{37}$ & Presence of lakes and ponds & Accept \\
\hline$C_{38}$ & Presence of plains and/or plateaus & Accept \\
\hline$C_{39}^{20}$ & Environmental and water pollution & Accept \\
\hline$C_{41}$ & Presence of natural parks & Accept \\
\hline$C_{44}$ & Traditional architecture & Accept \\
\hline$C_{45}$ & Traditional handicrafts & Accept \\
\hline$C_{47}$ & Hospitality & Accept \\
\hline$C_{48}$ & Attitude of the people in the region towards domestic tourists & Accept \\
\hline$C_{49}$ & Attitude of the people in the region towards foreign tourists & Accept \\
\hline$C_{52}$ & Perception of the personnel representing public authority towards agritourism & Accept \\
\hline$C_{54}$ & Image of the region and the people living there & Accept \\
\hline$C_{56}$ & Marketability of tourism activities & Accept \\
\hline$C_{57}$ & Marketability of agritourism & Accept \\
\hline$C_{58}$ & Presence of recreational activities & Accept \\
\hline$C_{59}$ & Presence of tourism types & Accept \\
\hline$C_{60}$ & Accommodation facilities & Accept \\
\hline$C_{61}$ & Access to public services & Accept \\
\hline$C_{62}$ & Support of non-governmental organizations & Accept \\
\hline$C_{67}$ & Processing of agricultural and livestock products & Accept \\
\hline$C_{68}$ & Sale of agricultural and livestock products & Accept \\
\hline$C_{71}$ & Promotion & Accept \\
\hline$C_{73}$ & Presence of rural roads & Accept \\
\hline$C_{74}$ & Dominance of landscape & Accept \\
\hline$C_{77}$ & Branded, specially labelled products & Accept \\
\hline$C_{78}$ & Connection to an international organization-network in agritourism & Accept \\
\hline$C_{79}$ & Number of young people in the region & Accept \\
\hline
\end{tabular}




\subsubsection{Calculation of the evaluation criteria for agritourism by means of AHP method}

In this stage, 52 decision criteria determined by means of the Delphi technique have been classified into 9 main categories in the first place. The main cri- teria are signified by " $M$ " in Table 6 while " $M_{i}$ " signifies the " $i$ " th main criterion $(i=1,2, \ldots 9)$. In the same table, " $\mathrm{C}$ " signifies the criteria included in the third round of the delphi technique, and " $C_{j}$ " signifies the " $j$ " th sub-criterion $(j=1,2, \ldots, 79)$.

Table 6: Main and Sub-Criteria

\begin{tabular}{|c|c|c|}
\hline Main Criteria $\left(M_{i}\right)$ & Sub-criteria No $\left(C_{j}\right)$ & Sub-criteria \\
\hline \multirow{7}{*}{$\begin{array}{l}M_{1}: \text { Demographic and } \\
\text { economic criteria }\end{array}$} & $C_{3}$ & Educational background \\
\hline & $\mathrm{C}_{4}$ & Income level \\
\hline & $C_{5}$ & Potential demand for agritourism \\
\hline & $C_{0}$ & Economic added value of agritourism \\
\hline & $C_{10}$ & Number of domestic and foreign tourists visiting the region \\
\hline & $C_{20}$ & Labor force employed in agricultural activities \\
\hline & $C_{79}$ & Number of young population in the region \\
\hline \multirow{8}{*}{$\begin{array}{l}M_{2}: \text { Criteria for natural } \\
\text { environment }\end{array}$} & $C_{7}$ & Presence and diversity of natural plants \\
\hline & $C_{35}$ & Presence of endemic plant species \\
\hline & $C_{36}$ & Presence of streams and rivers \\
\hline & $C_{37}$ & Presence of lakes and ponds \\
\hline & $C_{38}$ & Presence of plains and / or plateaus \\
\hline & $C_{39}$ & Environmental and water pollution \\
\hline & $C_{41}$ & Presence of natural parks \\
\hline & $C_{74}$ & Landscape dominance \\
\hline \multirow{10}{*}{$\begin{array}{l}M_{3}: \text { Criteria for agriculture } \\
\text { and animal husbandry }\end{array}$} & $C_{12}$ & Soil-based agricultural activities \\
\hline & $C_{13}$ & Ovine/caprine breeding \\
\hline & $C_{14}$ & Bovine breeding \\
\hline & $C_{15}$ & Poultry farming \\
\hline & $C_{16}$ & Fishing \\
\hline & $C_{17}$ & Beekeeping \\
\hline & $C_{18}$ & Number of farms \\
\hline & $C_{24}$ & Diversity of agricultural activities and products \\
\hline & $C_{67}$ & Processing of agricultural and livestock products \\
\hline & $C_{68}$ & Sale of agricultural and livestock products \\
\hline \multirow[t]{4}{*}{$M_{4}:$ Criteria for climate } & $C_{25}$ & Temperature \\
\hline & $C_{26}$ & Precipitation \\
\hline & $C_{27}$ & Wind \\
\hline & $C_{28}$ & Snow and frost condition \\
\hline \multirow{6}{*}{$\begin{array}{l}M_{5}: \text { Criteria for land and } \\
\text { land structure }\end{array}$} & $C_{29}$ & Soil productivity \\
\hline & $C_{30}$ & Irrigation water sufficiency \\
\hline & $C_{32}$ & Convincing land condition \\
\hline & $C_{33}$ & Land suitable for animal husbandry \\
\hline & $C_{34}$ & Transportability \\
\hline & $C_{73}$ & Presence of rural roads \\
\hline \multirow{3}{*}{$\begin{array}{l}M_{6}: \text { Criteria related to } \\
\text { cultural and historical } \\
\text { values }\end{array}$} & $C_{44}$ & Traditional architecture \\
\hline & $C_{45}$ & Traditional handicrafts \\
\hline & $C_{47}$ & Hospitality \\
\hline
\end{tabular}




\begin{tabular}{|c|c|c|}
\hline \multirow{8}{*}{$\begin{array}{l}M_{;}: \text {Marketing related } \\
\text { criteria }\end{array}$} & $C_{54}$ & Image of the region and the people living there \\
\hline & $C_{56}$ & Marketability of tourism activities \\
\hline & $C_{57}$ & Agritourism marketability \\
\hline & $C_{58}$ & Presence of recreational activities \\
\hline & $C_{59}$ & The presence of tourism types \\
\hline & $C_{60}$ & Accommodation facilities \\
\hline & $C_{71}$ & Promotion \\
\hline & $C_{77}$ & Branded, specially labelled products \\
\hline \multirow{3}{*}{$\begin{array}{l}M_{g}: \text { Criteria for } \\
\text { supporting activities }\end{array}$} & $C_{61}$ & Access to public services \\
\hline & $C_{62}$ & Support of non-governmental organizations \\
\hline & $C_{78}$ & $\begin{array}{l}\text { Connection to an international organization \& network in } \\
\text { agritourism }\end{array}$ \\
\hline \multirow{3}{*}{$M_{g}:$ Psychological criteria } & $C_{48}$ & Attitude of the people in the region towards domestic tourists \\
\hline & $C_{49}$ & Attitude of the people in the region towards foreign tourists \\
\hline & $C_{52}$ & $\begin{array}{l}\text { Perception of the personnel representing public authority towards } \\
\text { agritourism }\end{array}$ \\
\hline
\end{tabular}

12 experts have been asked to send their individual evaluations on the main and sub-criteria in order to calculate the weights of the criteria. The scale developed by Thomas L.Saaty and shown in Table 1 has been used for this purpose. The geometric mean of the individual evaluations has been calculated in order to obtain the judgment of the group through the analysis of individual evaluations. Pairwise comparison matrices have been constructed in this way. These matrices are shown in the Table 7-16 below.

Table 7: Pairwise comparison matrix for main criteria

\begin{tabular}{llllllllll}
\hline Criteria & $M_{1}$ & $M_{2}$ & $M_{3}$ & $M_{4}$ & $M_{5}$ & $M_{6}$ & $M_{7}$ & $M_{8}$ & $M_{9}$ \\
\hline$M_{1}$ & 1 & 0,25 & 0,33 & 0,33 & 0,5 & 0,25 & 0,5 & 2 & 1 \\
\hline$M_{2}$ & 4 & 1 & 1 & 3 & 1 & 1 & 1 & 4 & 2 \\
\hline$M_{3}$ & 3 & 1 & 1 & 1 & 1 & 1 & 1 & 3 & 1 \\
\hline$M_{4}$ & 3 & 0,33 & 1 & 1 & 0,5 & 0,5 & 1 & 2 & 2 \\
\hline$M_{5}$ & 2 & 1 & 1 & 2 & 1 & 1 & 1 & 2 & 2 \\
\hline$M_{6}$ & 4 & 1 & 1 & 2 & 1 & 1 & 2 & 2 & 2 \\
\hline$M_{7}$ & 2 & 1 & 1 & 1 & 1 & 0,5 & 1 & 3 & 3 \\
\hline$M_{8}$ & 0,5 & 0,25 & 0,33 & 0,5 & 0,5 & 0,5 & 0,33 & 1 & 1 \\
\hline$M_{9}$ & 1 & 0,5 & 1 & 0,5 & 0,5 & 0,5 & 0,33 & 1 & 1 \\
\hline
\end{tabular}

Table 8: Pairwise comparison matrix for demographic and economic criteria

\begin{tabular}{llllllll}
\hline Criteria & $C_{3}$ & $C_{4}$ & $C_{5}$ & $C_{9}$ & $C_{10}$ & $C_{20}$ & $C_{79}$ \\
\hline$C_{3}$ & 1 & 2 & 0,25 & 0,2 & 0,25 & 1 & 0,5 \\
\hline$C_{4}$ & 0,5 & 1 & 0,33 & 0,2 & 0,33 & 0,5 & 0,33 \\
\hline$C_{5}$ & 4 & 3 & 1 & 2 & 1 & 6 & 3 \\
\hline$C_{9}$ & 5 & 5 & 0,5 & 1 & 1 & 3 & 2 \\
\hline$C_{10}$ & 4 & 3 & 1 & 1 & 1 & 4 & 2 \\
\hline$C_{20}$ & 1 & 2 & 0,17 & 0,33 & 0,25 & 1 & 1 \\
\hline$C_{79}$ & 2 & 3 & 0,33 & 0,5 & 0,5 & 1 & 1 \\
\hline
\end{tabular}

Table 9: Pairwise comparison matrix for natural environment criteria

\begin{tabular}{lllllllll}
\hline Criteria & $C_{7}$ & $C_{35}$ & $C_{36}$ & $C_{37}$ & $C_{38}$ & $C_{39}$ & $C_{41}$ & $C_{74}$ \\
\hline$C_{7}$ & 1 & 2 & 0,5 & 0,5 & 2 & 0,5 & 0,5 & 0,33 \\
\hline$C_{35}$ & 0,5 & 1 & 0,5 & 0,33 & 1 & 0,5 & 0,33 & 0,33 \\
\hline$C_{36}$ & 2 & 2 & 1 & 0,5 & 2 & 1 & 1 & 0,33 \\
\hline$C_{37}$ & 2 & 3 & 2 & 1 & 3 & 0,5 & 0,5 & 0,25 \\
\hline$C_{38}$ & 0,5 & 1 & 0,5 & 0,33 & 1 & 0,5 & 0,5 & 0,33 \\
\hline$C_{39}$ & 2 & 2 & 1 & 2 & 2 & 1 & 1 & 1 \\
\hline$C_{41}$ & 2 & 3 & 1 & 2 & 2 & 1 & 1 & 0,33 \\
\hline$C_{74}$ & 3 & 3 & 3 & 4 & 3 & 1 & 3 & 1 \\
\hline
\end{tabular}

Table 10: Pairwise comparison matrix for climate criteria

\begin{tabular}{lllll}
\hline Criteria & $C_{25}$ & $C_{26}$ & $C_{27}$ & $C_{28}$ \\
\hline$C_{25}$ & 1 & 2 & 2 & 1 \\
\hline$C_{26}$ & 0,5 & 1 & 2 & 1 \\
\hline$C_{27}$ & 0,5 & 0,5 & 1 & 0,5 \\
\hline$C_{28}$ & 1 & 1 & 2 & 1 \\
\hline
\end{tabular}


Table 11: Pairwise comparison matrix for agriculture and animal husbandry criteria

\begin{tabular}{lllllllllll}
\hline Criteria & $C_{12}$ & $C_{13}$ & $C_{14}$ & $C_{15}$ & $C_{16}$ & $C_{17}$ & $C_{18}$ & $C_{24}$ & $C_{67}$ & $C_{68}$ \\
\hline$C_{12}$ & 1 & 2 & 2 & 2 & 2 & 2 & 2 & 1 & 1 & 0,5 \\
\hline$C_{13}$ & 0,5 & 1 & 2 & 2 & 2 & 2 & 1 & 0,33 & 0,5 & 0,33 \\
\hline$C_{14}$ & 0,5 & 0,5 & 1 & 1 & 2 & 2 & 2 & 0,33 & 0,5 & 0,33 \\
\hline$C_{15}$ & 0,5 & 0,5 & 1 & 1 & 1 & 1 & 0,5 & 0,25 & 0,33 & 0,25 \\
\hline$C_{16}$ & 0,5 & 0,5 & 0,5 & 1 & 1 & 1 & 2 & 0,25 & 0,2 & 0,2 \\
\hline$C_{17}$ & 0,5 & 0,5 & 0,5 & 1 & 1 & 1 & 1 & 0,33 & 0,33 & 0,33 \\
\hline$C_{18}$ & 0,5 & 1 & 0,5 & 2 & 0,5 & 1 & 1 & 0,33 & 0,25 & 0,25 \\
\hline$C_{24}$ & 1 & 3 & 3 & 4 & 4 & 3 & 3 & 1 & 1 & 0,5 \\
\hline$C_{67}$ & 1 & 2 & 2 & 3 & 5 & 3 & 4 & 1 & 1 & 1 \\
\hline$C_{68}$ & 2 & 3 & 3 & 4 & 5 & 3 & 4 & 2 & 1 & 1 \\
\hline
\end{tabular}

Table 12: Pairwise comparison matrix for land and land structıre criteria

\begin{tabular}{lllllll}
\hline Criteria & $C_{29}$ & $C_{30}$ & $C_{32}$ & $C_{33}$ & $C_{34}$ & $C_{73}$ \\
\hline$C_{29}$ & 1 & 1 & 1 & 1 & 0,33 & 0,5 \\
\hline$C_{30}$ & 1 & 1 & 1 & 1 & 0,5 & 0,5 \\
\hline$C_{32}$ & 1 & 1 & 1 & 1 & 0,5 & 1 \\
\hline$C_{33}$ & 1 & 1 & 1 & 1 & 0,33 & 2 \\
\hline$C_{34}$ & 3 & 2 & 2 & 3 & 1 & 4 \\
\hline$C_{73}$ & 2 & 2 & 1 & 0,5 & 0,25 & 1 \\
\hline
\end{tabular}

Table 13: Pairwise comparison matrix for cultural and historical criteria

\begin{tabular}{llll}
\hline Criteria & $C_{44}$ & $C_{45}$ & $C_{47}$ \\
\hline$C_{44}$ & 1 & 2 & 0,5 \\
\hline$C_{45}$ & 0,5 & 1 & 0,5 \\
\hline$C_{47}$ & 2 & 2 & 1 \\
\hline
\end{tabular}

Table 14: Pairwise comparison matrix for marketing criteria

\begin{tabular}{lllllllll}
\hline Criteria & $C_{54}$ & $C_{56}$ & $C_{57}$ & $C_{58}$ & $C_{59}$ & $C_{60}$ & $C_{71}$ & $C_{77}$ \\
\hline$C_{54}$ & 1 & 0,5 & 0,5 & 0,5 & 0,5 & 0,5 & 0,33 & 0,5 \\
\hline$C_{56}$ & 2 & 1 & 1 & 1 & 2 & 0,5 & 1 & 2 \\
\hline$C_{57}$ & 2 & 1 & 1 & 3 & 2 & 1 & 2 & 3 \\
\hline$C_{58}$ & 2 & 1 & 0,33 & 1 & 0,5 & 0,33 & 0,33 & 1 \\
\hline$C_{59}$ & 2 & 0,5 & 0,5 & 2 & 1 & 0,5 & 0,5 & 1 \\
\hline$C_{60}$ & 2 & 2 & 1 & 3 & 2 & 1 & 1 & 3 \\
\hline$C_{71}$ & 3 & 1 & 0,5 & 3 & 2 & 1 & 1 & 3 \\
\hline$C_{77}$ & 2 & 0,5 & 0,33 & 1 & 1 & 0,33 & 0,33 & 1 \\
\hline
\end{tabular}

Table 15: Pairwise comparison matrix for supporting activities criteria

\begin{tabular}{llll}
\hline Criteria & $C_{61}$ & $C_{62}$ & $C_{78}$ \\
\hline$C_{61}$ & 1 & 0,5 & 0,5 \\
\hline$C_{62}$ & 2 & 1 & 1 \\
\hline$C_{78}$ & 2 & 1 & 1 \\
\hline
\end{tabular}

Table 16: Pairwise comparison matrix for psychological criteria

\begin{tabular}{llll}
\hline Criteria & $C_{48}$ & $C_{49}$ & $C_{52}$ \\
\hline$C_{48}$ & 1 & 1 & 2 \\
\hline$C_{49}$ & 1 & 1 & 1 \\
\hline$C_{52}$ & 0,5 & 1 & 1 \\
\hline
\end{tabular}

After the construction of the pairwise comparison matrices, the normalized pairwise comparison matrices and the priority vector have been constructed, respectively. In the next phase, the local and global weights of the criteria have been calculated with excel. After the determination of the local and global weights, calculations have been made in order to find out whether the inconsistency is at an acceptable level for all pairwise comparison matrices. These calculations have shown that the Consistency Ratios in all matrices are less than 0,1. Accordingly, it has been concluded that the inconsistency is at an acceptable level for all pairwise comparison matrices.

According to the results of the calculations on the main criteria, the consistency ratio of the pairwise comparison matrix constructed for the main criteria is 0,032666 . This ratio indicates that the inconsistency of the pairwise comparison matrix for the main criteria is at an acceptable level. The main criteria included in the calculations are respectively given as follows: "Criteria for natural environment", "Criteria related to cultural and historical values", "Criteria related for land and land structure", "Criteria related to marketing", "Criteria for agriculture and animal husbandry", "Criteria for climate", "Psychological criteria", "Demographic and economic criteria" and "Criteria for supporting activities". The weights of the first 6 main criteria range from $10 \%$ to $16 \%$ while the weights of the last three main criteria range from $5 \%$ to $6 \%$. The results reveal that "psychological criteria", "demographic and economic criteria" and "criteria related to supporting activities" which are among the main criteria for the decision-making group are less important in terms of agritourism than the other six criteria. The criteria rela- 
ted to the natural environment have been found to be the most significant category in terms of agritourism with its weight of 0,167463 . In addition to this, $\mathrm{Cl}$ and
$C R$ values and weights calculated for the sub-criteria are given in Table 17.

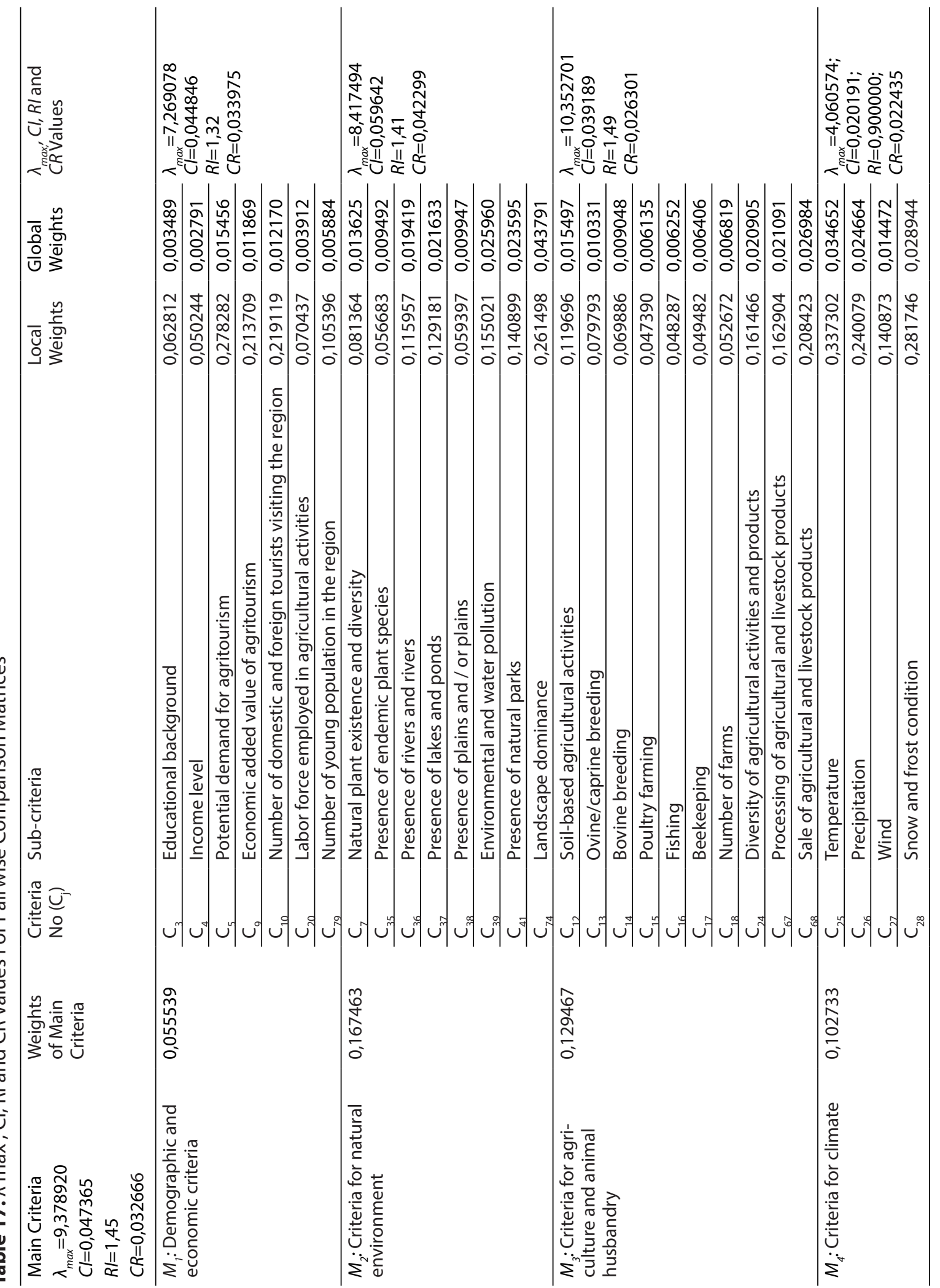




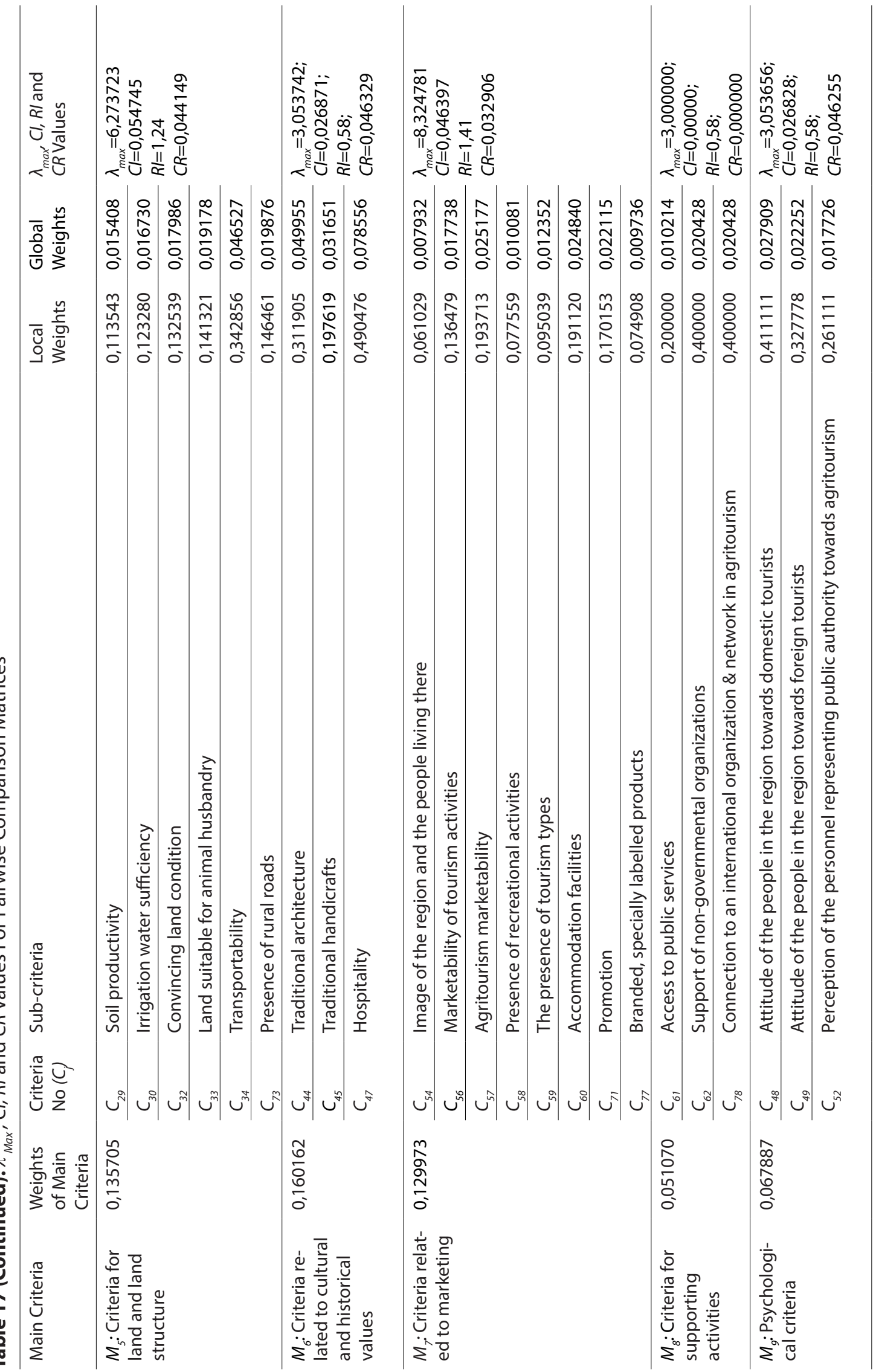


According to Table 17, the main demographic and economic criterion, which has a weight of 0,055539 includes 7 sub-criteria. These sub-criteria have been arranged according to their local and global weights and listed respectively in the following order: "Potential demand for agritourism", "Number of domestic and foreign tourists visiting the region", "Economic added-value of agritourism", "Number of young people in the region", "Labor force employed in agricultural activities", "Educational background" and "Income level". "The potential demand for agritourism" has been found to be the most important sub-criterion with its local weight of 0,278282 and global weight of 0,015456 within the scope of the main "economic and demographic" criterion. "Income level", on the other hand, have been determined to be the least important sub-criteria with its local weight of 0,050244 and global weight of 0,002791 .

The main criterion related to natural environment, which has a weight of 0,167463 ; includes 8 sub-criteria. These sub-criteria have been arranged according to their local and global weights and listed respectively in the following order: "Landscape dominance", "Environmental and water pollution", "Presence of natural parks", "Presence of lakes and ponds", "Presence of streams and rivers", "Presence and diversity of natural plants", "Presence of plains and/or plateaus" and "Presence of endemic plant species". "The dominance of landscape" has been found to be the most significant sub-criterion with its local weight of 0,261498 and global weight of 0,043791 within the scope of the main criterion related to the "natural environment". "Presence of endemic plant species" has been revealed to be the least important sub-criterion with its local weight of 0,056683 and global weight of 0,009492.

There are 10 sub-criteria within the scope of the main criterion related to "agriculture and animal husbandry", which has a weight of 0,129467. These sub-criteria have been respectively listed according to their local and global weight as follows: "Sale of agricultural and livestock products", "Processing of agricultural and livestock products", "Diversity of agricultural activities and products", "Soil-based agricultural activities", "Ovine/caprine breeding", "Bovine breeding", "Number of farms", "Beekeeping", "Fishing" and "Poultry farming". "The sale of agricultural and livestock products" has been found to be the most significant sub-criterion with its local weight of 0,208423 and global weight of 0,026984 within the scope of the main criterion related to the "agriculture and animal husbandry". The least important sub-criterion is "the poultry farming" with its local weight of 0,047390 and global weight of 0,006135 .

There are 4 sub-criteria within the scope of the main criterion related to "climate" having a weight of 0,102733 . These sub-criteria are listed according to their local and global weights as follows: "Temperature", "Snow and frost condition", "Precipitation" and "Wind". The "temperature" has been found to be the most significant sub-criterion with its local weight of 0,337302 and global weight of 0,034652 within the scope of the main criterion related to the "climate". The "wind" is the least significant sub-criterion with its local weight of 0,140873 and global weight of 0,014472.

6 sub-criteria have been included within the scope of the main criterion related to "land and land structure" having a weight of 0,135705 . These sub-criteria have been arranged according to their local and global weights and listed respectively in the following order: "Transportability", "Presence of rural roads", "Lands suitable for animal husbandry", "Lands suitable for agriculture", "Sufficiency of irrigation water" and "Soil productivity". "Transportability" has been found to be the most important sub-criterion with its local weight of 0,342856 and global weight of 0,046527 within the scope of the main criterion related to "land and land structure". In this context, the least important sub-criterion is the "soil productivity" with its local weight of 0,113543 and global weight of 0,015408 .

3 sub-criteria have been included within the scope of the main criterion related to "cultural and historical values" which has a weight of 0,160102 . These sub-criteria are respectively listed according to their local and global weights as follows: "Hospitality", "Traditional architecture" and "Traditional handicrafts". The sub-criterion of "hospitality" has a local weight of 0,490476 and a global weight of 0,078556 . The local weight of the sub-criterion of "traditional architecture" is 0,311905 while its global weight is 0,049955 . Finally, the local weight of the sub-criterion of "traditional handicrafts" is 0,197619 and its global weight is 0,031651.

There are 8 sub-criteria within the scope of the main criterion related to "marketing", which has a weight of 0,129973 . These sub-criteria are listed according to their local and global weights as follows: "Marketability of agritourism", "Accommodation facilities", "Promotion", "Marketability of tourism activities", "Presence of tourism types", "Presence of recreational activities", "Branded, specially labelled products" and 
"Image of the region and the people living there". The "marketability of agritourism" is the most significant sub-criterion with a local weight of 0,193713 and a global weight of 0,025177 within the scope of the main criterion of "marketing". The least important sub-criterion is "the image of the region and the people living there" with a local weight of 0,061029 and a global weight of 0,007932.

3 sub-criteria have been included within the scope of the main criterion related to "supporting activities" having a weight of 0,051070 . These sub-criteria are respectively listed according their local and global weights as follows: "Support of non-governmental organizations", "Connection to an international organization \& network in agritourism" and "Access to public services". The local and global weights of the sub-criteria entitled "the support of non-governmental organization" and "the connection to an international organization \& network in agritourism" have been found to be equal. The local weight of these sub-criteria has been calculated as 0,400000 while their global weight has been recorded as 0,020428. The local weight of the sub-criterion entitled "access to public services" is 0,200000 while its global weight has been calculated as 0,010214.

Finally, there are 3 sub-criteria within the scope of the main "psychological" criterion, which has a weight of 0,067887 . These sub-criteria have been arranged according to their local and global weights and listed respectively in the following order: "Attitude of the people in the region towards domestic tourists", "Attitude of the people in the region towards foreign tourists" and "Perception of the personnel representing public authority towards agritourism". The sub-criterion entitled "the attitude of the people in the region towards domestic tourists" has a local weight of 0,411111 and a global weight of 0,027909 . The sub-criterion entitled "the attitude of the people in the region towards foreign tourists" has a local weight of 0,327778 and a global weight of 0,022252 . The sub-criterion entitled "perception of the personnel representing public authority towards agritourism" has a local weight of 0,261111 and a global weight of 0,017726 .

\section{CONCLUSION AND RECOMMENDATIONS}

This study has been carried out for the purpose of contributing to the elimination of the negative situations in the planning process of the agritourism, and due to the lack of evaluation criterion in the literature for determining whether a region is suitable for agritourism or not. From this point of view, in this study, it has been aimed to determine the evaluation criteria, which can be used to compare the potentials of agricultural regions in terms of agritourism and to calculate their weights.

The Delphi technique, which is based on the acquisition of experts' opinions, has been used to determine the evaluation criteria for agritourism. In this way, the decision criteria agreed upon by the experts have been determined. 52 decision criteria agreed upon on the issue of agritourism have been listed with the use of the Delphi technique. These criteria have not been mentioned here since they have been elaborated in detail in the previous sections. After the determination of the criteria, it has been needed to calculate their weights. For this purpose, it has been used AHP.

The results obtained from the AHP have illustrated that the main criteria are listed according to their significance level as follows: "Criteria related to natural environment", "Criteria related to cultural and historical values", "Criteria for land and land structure", "Criteria related to marketing", "Criteria for agriculture and animal husbandry", "Criteria for climate", "Psychological criteria", "Demographic and economic criteria" and "Criteria for supporting activities".

When the sub-criteria have been evaluated within their own scope, it has been found out that the most significant demographic and economic criterion is the sub-criterion of potential demand for agritourism while the least significant sub-criterion is the level of income; that the most significant sub-criterion related to natural environment is the dominance of landscape while the least significant sub-criterion is the presence of plains and/or plateaus; that the most important sub-criterion related to agriculture and animal husbandry is the sale of agricultural and animal products while the least important sub-criterion is the poultry breeding; that the most significant sub-criterion related to climate is the temperature while the least significant sub-criterion is the wind; that the most significant sub-criterion related to land and land structure is the transportability while the least significant sub-criterion is the soil fertility; that the most significant sub-criterion related to cultural and historical values is the hospitality while the least significant sub-criterion is the traditional handicrafts; that the most significant sub-criterion related to marketing is the marketability of the agritourism while the least significant sub-criterion is the image of the region 
and the people living there; that the most significant sub-criteria related to supporting activities are the support of non-governmental organizations and the connection to an international organization/network while the least significant sub-criterion is the access to public services; the most significant psychological sub-criterion is the attitude of the people living in the region towards domestic tourists while the least significant sub-criterion is the perception of the personnel representing public authority towards agritourism.

The research shows that agritourism can contribute to the reduction of the growing gap between people and nature because the results of the analysis have indicated that the most important criteria in terms of agritourism are the ones related to the natural environment. However, the criteria of traditional architecture, dominance of landscape and transportability are listed in the first three places respectively in the order of significance for the criteria. This ranking among the sub-criteria indicates the importance of the region selection for agritourism projects. The results of the analysis illustrate that agritourism is a touristic activity providing an opportunity for the tourists to meet the nature, to know the traditional lifestyle and architecture and to have access to the natural products on condition that the selected region is suitable for agritourism.

It is important to note that the study has been conducted in Turkey although the relevant criteria have been determined to be used in any region for the evaluation of agritourism potentials, and that the results obtained in this study might not be applicable in different countries. A research that will be carried out with a higher rate of participation from different countries will abolish this limitation to some extent. Moreover, it should be remembered that numerous decision-making techniques including Delphi and AHP can be used in the further studies, which rankings and selections can be made for regions through the use of these techniques. 


\section{REFERENCES}

Ahipaşaoğlu , S. \& Çeltek, E. (2006). Sürdürülebilir Kırsal Turizm. Gazi Kitabevi, Ankara

Aikaterini, G., loannis, S., \& Thanasis, K. (2001). Is agrotourism 'agro'or 'tourism'? Evidence from agrotourist holdings in Lesvos, Greece. Anatolia, 12 (1), 6-22.

Akgül, A. ve Çevik, O. (2005). İstatistiktiksel Analiz Teknikleri "SPSS"te İşletme Yönetimi Uygulamaları". Emek Ofset, Ankara.

Akins, R. B., Tolson, H., \& Cole, B. R. (2005). Stability of response characteristics of a Delphi panel: application of bootstrap data expansion. BMC medical research methodology, 5(1), 1-12.

Aktaş, R., Doğanay, M.M., Gökmen, Y., Gazibey, Y., \& Türen, U. (2015). Sayısal Karar Verme Yöntemleri. Beta Yayınları, İstanbul.

Blancas, F. J., Lozano-Oyola, M., González, M., Guerrero, F. M., \& Caballero, R. (2011). How to use sustainability indicators for tourism planning: The case of rural tourism in Andalusia (Spain). Science of the Total Environment, 412, 28-45.

Briedenhann, J., \& Butts, S. (2006). Application of the Delphi technique to rural tourism project evaluation. Current Issues in Tourism, 9 (2), 171-190.

Busby, G. \& Rendle, S. (2000). The Transition From Tourism on Farms to Farm Tourism,.Tourism Management, 21 (6),635-642.

Çelikbilek, Y. (2018). Çok Kriterli Karar Verme Yöntemleri Açıklamalı ve Karşılaştırmalı Sağlık Bilimleri Uygulamaları İle (Editör: D.Muhlis Özdemir). Nobel Yayınları, Ankara.

Choi, H. C., \& Sirakaya, E. (2006). Sustainability indicators for managing community tourism. Tourism management, 27 (6), 1274-1289.

Dağdeviren, M.; Yavuz, S. ve Kılınç, N. (2009). Weapon Selection Using the AHP and TOPSIS Methods Under Fuzzy Environment. Expert Systems with Applications, 36, 8143-8151.

Dalkey, N., \& Helmer, O. (1963). An experimental application of the Delphi method to the use of experts. Management science, 9 (3), 458-467.

Deng, X., Hu, Y., Deng, Y., Mahadevan, S. (2014). Supplier selection using AHP methodology extended by D numbers. Expert Systems with Applications, 41, 156167.

Dymond, S. J. (1997). Indicators of sustainable tourism in New Zealand: A local government perspective. Journal of sustainable tourism, 5 (4), 279-293.
Fischer, R. G. (1978). The Delphi method: a description, review and criticism. Journal of Academic Librarianship, 4(2), 64-70.

Fusfeld, A. R., \& Foster, R. N. (1971). The Delphi technique: Survey and comment: Essentials for corporate use. Business Horizons, 14 (3), 63-74.

Gordean, R. S., Buzilă, N., \& Dragotă, G. (2009). Agrotourism-a viable alternative of county development. Agricultural Management/Lucrari Stiintifice Seria I, Management Agricol, 11 (4).

Green, B., Jones, M., Hughes, D., \& Williams, A. (1999). Applying the Delphi technique in a study of GPs' information requirements. Health \& social care in the community, 7 (3), 198-205.

Hasson, F., Keeney, S., \& McKenna, H. (2000). Research guidelines for the Delphi survey technique. Journal of advanced nursing, 32 (4), 1008-1015.

Hsu, C. C., \& Sandford, B. A. (2007). The Delphi technique: making sense of consensus. Practical assessment, research \& evaluation, 12 (10), 1-8.

Hung, H. L., Altschuld, J. W., \& Lee, Y. F. (2008). Methodological and conceptual issues confronting a cross-country Delphi study of educational program evaluation. Evaluation and Program Planning, 31 (2), 191-198.

Hunter, C., \& Shaw, J. (2007). The ecological footprint as a key indicator of sustainable tourism. Tourism management, 28 (1), 46-57.

lakovidou, O., Emmanouilıdou, M., Stavrakas, T., Sımeonıdou, P., \& Chrısostomıdıs, C. D. (2001). Trends of tourism market for agro-tourism. Anatolia, 12 (2), 165-179.

Jolson, M. A., \& Rossow, G. L. (1971). The Delphi process in marketing decision making. Journal of Marketing Research, 443-448.

Keeney, S., McKenna, H., \& Hasson, F. (2011). The Delphi technique in nursing and health research. John Wiley \& Sons.

Kılıç, B., \& Kurnaz, A. (2010). Alternative Tourism and Ecological Farms on Creating Diversification of Tourism Product: Example of Pastoral Valley. Journal of Business Research-Turk, 2 (4), 39-56.

Kızılaslan, N., \& Ünal, T. (2013). Determination of Rural Tourism Potential of Manisa Spil Mountain National Park, Gaziosmanpasa Journal of Scientific Research, (7), 10-29.

Ko, J. T. (2001). Assessing progress of tourism sustainability. Annals of Tourism Research, 28 (3), 817-820. 
Kozak Akoğlan, M. \& Bahçe, A. S. (2009). Özel İlgi Turizmi, Detay Yayıncılık, Ankara.

Landeta, J. (2006). Current validity of the Delphi method in social sciences. Technological forecasting and social change, 73 (5), 467-482.

Linstone, H. \& Turoff, M. (2002). The Delphi method: Techniques and applications. Retrieved March.

López, E. P., \& García, F. J. C. (2006). Agrotourism, sustainable tourism and ultraperipheral areas: the case of Canary Islands. PASOS. Revista de Turismoy Patrimonio Cultural, 4 (1), 85-97.

Loughlin, K. G., \& Moore, L. F. (1979). Using Delphi to achieve congruent objectives and activities in a pediatrics department. Academic Medicine, 54 (2), 101-106.

McKenna, H. P. (1994). The Delphi technique: a worthwhile research approach for nursing?. Journal of advanced nursing, 19(6), 1221-1225.

Mearns, K. (2012). Lessons from the application of sustainability indicators to community-based ecotourism ventures in Southern Africa. African Journal of Business Management, 6 (26), 7851-7860.

Miller, G. (2001). The development of indicators for sustainable tourism: results of a Delphi survey of tourism researchers. Tourism management, 22 (4), 351-362.

Möller, P., M. Thulemark, Engström C. (2014). Rural tourism an international perspective (Edithor: Katherine Dashper). Newcastle-upon-Tyne, UNITED KINGDOM: Cambridge Scholars Publishing.

Newbold, P. (1995). İşletme ve İktisat için İstatistik (Çeviren: Ümit Şenesen), Literatür Yayıncılık.

Özbek, A. (2017). Çok Kriterli Karar Verme Yöntemleri ve Excel İle Problem Çözümü Kavram-Teori-Uygulama, Seçkin Yayınları, Ankara

Park, D. B., \& Yoon, Y. S. (2011). Developing sustainable rural tourism evaluation indicators. International Journal of Tourism Research, 13 (5), 401-415.

Phillip, S., Hunter, C., \& Blackstock, K. (2010). A typology for defining agritourism. Tourism Management, 31 (6), 754-758.

Procter, S., \& Hunt, M. (1994). Using the Delphi survey technique to develop a professional definition of nursing for analysing nursing workload. Journal of advanced nursing, 19 (5), 1003-1014.

Reed, M. S., Fraser, E. D., \& Dougill, A. J. (2006). An adaptive learning process for developing and applying sustainability indicators with local communities. Ecological economics, 59 (4), 406-418.
Saaty, T.L. (1986). Axiomatic Foundation of the Analytic Hierarchy Process, Management Science. 32 (7), 841-855.

Saaty, T.L. (1987). The Anaytic Hierarchy Process - What It Is and How It Is Used, Mathl.Modelling, 9, 3-5, 161-176.

Saaty, T.L. (2008). Decision making with the analytic hierarchy process. Int. J. Services Sciences, 1 (1), 83-98.

Sarıkamış, M. ve Bahar, O. (2013). Turizm, Yoksulluk ve Bölgesel Gelişmişlik Farklılıkları, Detay Yayıncılık, Ankara.

Sharpley, R. (2002). Rural tourism and the challenge of tourism diversification: the case of Cyprus. Tourism management, 23 (3), 233-244.

Siow, M. L., Abidin, Z.Z., Nair, V., Ramachandran, S.\& Shuid, A. (2011). Developing criteria and indicators for responsible rural tourism in Taman Negara National Park (TNNP), Malaysia, The Malaysian Forester, 74 (2):143-156.

Skulmoski, G. J., Hartman, F. T., \& Krahn, J. (2007). The Delphi method for graduate research. Journal of information technology education, 6, 1 .

Thangaratinam, S., \& Redman, C. W. (2005). The delphi technique. The obstetrician \& gynaecologist, 7 (2), 120-125.

Tsaur, S. H., \& Wang, C. H. (2007). The evaluation of sustainable tourism development by analytic hierarchy process and fuzzy set theory: An empirical study on the Green Island in Taiwan. Asia Pacific Journal of Tourism Research, 12 (2), 127-145.

Twining-Ward, L., \& Butler, R. (2002). Implementing STD on a small island: Development and use of sustainable tourism development indicators in Samoa. Journal of Sustainable Tourism, 10 (5), 363-387.

Van de Ven, A. H., \& Delbecq, A. L. (1974). The effectiveness of nominal, Delphi, and interacting group decision making processes. Academy of management Journal, 17 (4), 605-621.

Williams, P. L., \& Webb, C. (1994). The Delphi technique: a methodological discussion. Journal of advanced nursing, 19 (1), 180-186.

Woudenberg, F. (1991). An evaluation of Delphi. Technological forecasting and social change, 40 (2), 131-150.

Yavuzaslanoğlu, E., \& Yavuz, M. (2012). Agritourism Potantial of Karaman. Journal of Social and Economic Research, 2012 (1), 31-33.

Yıldırım, B.F.,\&Önder, E. (2014). Isşletmeciler, Mühendisler ve Yöneticiler için Operasyonel, Yönetsel ve Stratejik Problemlerin Çözümünde Çok Kriterli Karar Verme Yöntemleri, Dora Yayıncılık, Bursa. 
Zeliff, N., \& Heldenbrand, S. (1993). What's being done in the international business curriculum. Business Education Forum, 48 (1), 23-25. 